\title{
PENDEKATAN IN SILICO DALAM MENYINGKAP POTENSI ANTIKANKER MECIADANOL
}

\author{
Arif Fadlan ${ }^{1 *}$, Tri Warsito ${ }^{1}$, Sarmoko $^{2}$ \\ ${ }^{1}$ Departemen Kimia, Fakultas Sains dan Analitika Data, Institut Teknologi Sepuluh Nopember \\ ${ }^{2}$ Departemen Farmasi, Fakultas Ilmu Kesehatan, Universitas Jenderal Soedirman \\ *email: afadlan@chem.its.ac.id
}

Received 30 Oktober 2021

Accepted 5 Desember 2021

\begin{abstract}
Abstrak
Meciadanol merupakan flavanol katekin termetilasi pada posisi C3 yang mampu menghambat pembentukan histamin oleh histidin dekarboksilase. Senyawa ini merupakan target menarik dalam pengembangan agen antikanker karena histamin diketahui terlibat dalam perkembangan kanker. Histamin juga dilaporkan dapat berkaitan dengan death associated protein kinase 1 (DAPK1) yang berhubungan dengan apoptosis. Penelitian ini mempelajari potensi aktivitas antikanker meciadanol terhadap DAPK1 secara in silico. Penambatan molekul terhadap protein DAPK1 (kode 5AUX dan 5AV3) dilakukan dengan Autodock Vina yang dilanjutkan dengan evaluasi sifat fisikokimia dan profil ADMET menggunakan SwissADME dan pkCSM. Nilai afinitas ikatan meciadanol terhadap 5AUX dan 5AV3 masing-masing sebesar -7,4 kkal/mol dan -7,0 kkal/mol. Meciadanol selanjutnya tidak melanggar aturan Lipinski, Ghose, Veber, Egan dan Muegge, dan memiliki profil ADMET yang baik berdasarkan deskriptor evaluasi.
\end{abstract}

Kata kunci: Antikanker, in silico, meciadanol

\begin{abstract}
Meciadanol is a C3 methylated catechin with flavanol structure which can inhibit histidine decarboxylase to produce histamine. Meciadanol is an attractive target in the development of anticancer agents due to the important role of histamine in cancer development. Histamine has also been linked to death associated protein kinase 1 (DAPK1), a protein involved in apoptosis. In this study, the anticancer potential of meciadanol against DAPK1 was investigated in silico. Molecular docking against DAPK1 protein (5AUX and 5AV3) was performed using Autodock Vina followed by evaluation of the physicochemical properties and ADMET prediction using Swiss ADME and pkCSM. The binding affinity values of meciadanol for 5AUX and $5 \mathrm{AV} 3$ were $-7.4 \mathrm{kcal} / \mathrm{mol}$ and $-7.0 \mathrm{kcal} / \mathrm{mol}$, respectively. Further, meciadanol did not violate Lipinski, Ghose, Veber, Egan and Muegge rules, and had a good ADMET profile based on evaluation descriptors.
\end{abstract}

Keywords: Anticancer, in silico, meciadanol 


\section{Pendahuluan}

Meciadanol adalah katekin dengan struktur flavanol yang termetilasi pada posisi C3 (Gambar 1). Meciadanol menghambat histidin dekarboksilase untuk menghasilkan histamin yang berperan dalam sekresi asam lambung. Selanjutnya, meciadanol diketahui dapat mencegah terjadinya luka akibat mukosa lambung yang dapat disebabkan oleh aspirin dan ibuprofen. Meciadanol juga aman terhadap asam lambung atau pepsin pada berbagai dosis dibandingkan obat asam lambung 16,16-dimetil PGE2 (Konturek et al., 1986).<smiles>Oc1cc(O)c2c(c1)O[C@H](c1ccc(O)c(O)c1)[C@H](O)C2</smiles><smiles>CO[C@H]1Cc2c(O)cc(O)cc2O[C@H]1c1ccc(O)c(O)c1</smiles>

Gambar 1. Struktur katekin dan meciadanol

Histamin adalah salah satu mediator dalam inflamasi dan respon imun tubuh yang dilaporkan terdapat dalam berbagai tipe kanker yang berbeda (Moya-Garcia et al., 2021; Nguyen \& Cho, 2021). Histamin berperan dalam sistem biologi kanker dan merangsang perkembangan kanker seperti invasi sel, migrasi, dan angiogenesis (Nguyen \& Cho, 2021). Akibatnya, senyawa-senyawa yang menghambat pembentukan histamin merupakan target menarik dalam pengembangan agen antikanker (Barton et al., 2018).

Aktivitas penghambatan histamin dapat berkaitan dengan death associated protein kinase 1 (DAPK1) yang mendorong apoptosis. Aktivitas ini berhubungan dengan kemampuan meningkatkan DAPK1 dalam sel karsinoma nasofaring CNE1 sebagaimana dihasilkan oleh grifolin yang merupakan senyawa metabolit sekunder dalam jamur Albatrellus confluens (Ye et al., 2007). Grifolin juga dapat menghambat pertumbuhan dan invasi sel kanker gastrik manusia BGC823 dan SGC-7901 melalui induksi apoptosis (Nukata et al., 2002; Wu dan $\mathrm{Li}, 2017$ ).

Berdasarkan uraian tersebut, penelitian ini bertujuan untuk mengkaji potensi antikanker meciadanol terhadap DAPK1 secara in silico. Hal ini juga selaras dengan penggunaan kembali obat untuk indikasi lain (drug repurposing atau drug repositioning) yang dapat dilakukan secara komputasi (in silico drug repurposing) (Park, 2019).

\section{Metode Penelitian}

\section{Penambatan molekular}

Studi in silico dalam penelitian ini menggunakan Hawlett Packard sistem operasi Windows 10 64-bit prosesor Intel ${ }^{\circledR}$ Core $^{\mathrm{TM}} \mathrm{i} 5-8265 \mathrm{U}$ CPU @ $1.60 \mathrm{GHz}$ RAM 8 GB Radeon 530 Series. Penambatan molekular meciadanol dilakukan terhadap reseptor DAPK1 (kode 5AUX dan 5AV3) dengan ligan alami kaempferol (KMP) (Yokoyama et al., 2015). Struktur dua dimensi (2D) dan tiga dimensi (3D) meciadanol disiapkan dengan MarvinSketch yang dilanjutkan dengan peminimalan energi menggunakan MMFF94 dan protonasi pada $\mathrm{pH} 7,40$. Struktur 3D meciadanol hasil preparasi disimpan dalam format .sdf. Struktur 3D ligan alami KMP disiapkan dari 5AUX dan 5AV3 dengan PyMOL dan disimpan dalam format .sdf yang selanjutnya diubah menjadi format .pdbqt dengan PyRx-0.8 (Autodock Vina). Reseptor DAPK1 kode 5AUX dan 5AV3 resolusi 1,5 A dan 1,9 didapatkan dari protein data bank (PDB) dan disiapkan dengan PyMOL. Pelarut berupa air dan ligan alami KMP dihapus dari reseptor dan dilakukan penambahan 
atom hidrogen polar pada struktur meciadanol. Reseptor DAPK1 kode 5AUX dan 5AV3 hasil preparasi selanjutnya disimpan dalam format .pdb yang kemudian diubah menjadi format .pdbqt dengan Autodock Vina (Trott \& Olson, 2009; Dallakyan \& Olson, 2015). Penambatan ulang (redocking) ligan alami KMP kemudian dilakukan untuk validasi proses penambatan yang dilanjutkan dengan penambatan silang (cross-docking) meciadanol terhadap 5AUX dan 5AV3. Sumbu koordinat pada penambatan diatur pada $\mathrm{X}=-22,6677 \AA, \mathrm{Y}=2,3011 \AA, \mathrm{Z}=$ $11,9472 \AA$ dengan dimensi grid box $\mathrm{X}=$ $10,5001 \AA, Y=10,0118 \AA, Z=7,0530 \AA$ untuk 5AUX, sedangkan untuk 5AV3 diatur pada $X=-22,4249 \AA, Y=2,0250 \AA$, $\mathrm{Z}=-11,4906 \AA$ dan dimensi grid box $\mathrm{X}=$ $9,6792 \AA, Y=10,6855 \AA, Z=7,1940 \AA$. PyMOL, BIOVIA Discovery Studio, dan LigPlot+ digunakan untuk visualisasi hasil penambatan.

\section{Sifat fisikokimia dan profil ADMET}

Pengidentifikasi struktur meciadanol dalam bentuk simplified molecular input line entry specification (SMILES) dari National Center for Biotechnology Information (NCBI) dimasukkan dalam SwissADME dan pkCSM (Daina et al., 2017; Pires et al., 2015) untuk evaluasi sifat fisikokimia dan profil penyerapan, distribusi, metabolisme, ekskresi, toksisitas (ADMET). Sifat fisikokimia berupa data berat molekul, koefisien partisi oktanol-air, jumlah akseptor ikatan hidrogen, jumlah donor ikatan hidrogen, dan topological surface area (TPSA) digunakan untuk evaluasi drug-likeness berdasarkan aturan Lipinski. Kajian sifat fisikokimia lebih lanjut dilakukan dengan filter Ghose, Veber, Egan, dan Muegge melalui data jumlah atom, jumlah atom aromatis, fraksi karbon sp3, jumlah rotatable bonds, molar refractivity, XLogP, WLogP, dan skor bioavailabilitas. Profil ADMET untuk penyerapan berupa deskriptor kelarutan dalam air, permeabilitas Caco-2, penyerapan intestinal manusia, permeabilitas kulit, substrat dan inhibitor P-glikoprotein. Deskriptor distribusi dalam ADMET berupa volume distribusi steady state, fraksi tak terikat pada serum protein, permeabilitas blood-brain barrier (BBB), dan permeabilitas sistem saraf pusat. Metabolism dalam ADMET diwakili oleh deskriptor inhibitor dan substrat isoform sitokrom P450, sedangkan sifat ekskresi ADMET merujuk pada deskriptor total clearance dan renal OCT2 substrate. Toksisitas ADMET memiliki deskriptor toksisitas AMES, dosis toleransi maksimum, inhibitor hERG I, inhibitor hERG II, toksisitas akut oral (LD50), toksisitas kronis oral (LOAEL), hepatoksisitas, sensitisasi kulit, toksisitas Tetrahymena pyriformis, dan toksisitas Minnow.

\section{Hasil dan Pembahasan \\ Penambatan molekular}

Pada penelitian ini, studi penambatan meciadanol terhadap reseptor death associated protein kinase 1 (DAPK1) dilakukan dengan Autodock Vina dan hasil yang diperoleh divisualisasi dengan PyMOL, BIOVIA Discovery Studio, dan LigPlot+. Sebelum proses penambatan, meciadanol dan protein target DAPK1 disiapkan terlebih dahulu. Ligan alami KMP diperoleh dari penghapusan residu DAPK1. Meciadanol dan KMP disiapkan dengan MarvinSketch dan dilanjutkan dengan peminimalan energi menggunakan medan gaya MMFF94 (Jász et al., 2019). Proses minimisasi energi diperlukan untuk kestabilan ikatan karena meciadanol dan KMP bergerak bebas (flexible ligand) selama penambatan (Mirzaei et al., 2015). Selanjutnya, protonasi dilakukan pada $\mathrm{pH}$ 7,4 sehingga sesuai dengan kondisi sitoplasma sel (Drie, 2005). Meciadanol dan KMP yang telah disiapkan disimpan sebagai .sdf dan diubah sebagai .pdbqt.

Penyiapan protein target DAPK1 (kode 5AUX dan 5AV3) dilakukan dengan penghapusan KMP dan molekul air yang berada dalam kristal protein. Penghapusan 
KMP memberikan area penambatan untuk 5AUX pada koordinat $\mathrm{X}=-22,6677 \AA$, $\mathrm{Y}$ $=2,3011 \AA, Z=-11,9472 \AA$ dan ukuran grid box pada $\mathrm{X}=10,5001 \AA$, $\mathrm{Y}=10,0118$ $\AA, Z=7,0530 \AA$, dan untuk 5AV3 pada koordinat $\mathrm{X}=-22,4249 \AA, \mathrm{Y}=2,0250 \AA$, $\mathrm{Z}=-11,4906 \AA$ dan ukuran grid box $\mathrm{X}=$ $9,6792 \AA, Y=10,6855 \AA, Z=7,1940 \AA$. Penghapusan molekul air bertujuan untuk menghindari kompleksitas selama proses penambatan (Cole et al., 2005). Protein target selanjutnya disimpan sebagai .pdb dan diubah sebagai .pdbqt yang siap untuk penambatan.

Penambatan meciadanol dan KMP dalam penelitian ini dilakukan secara fleksibel (flexible ligand) dan selektif (selective docking) pada koordinat dan gridbox situs ikat KMP dalam 5AUX dan 5AV3. Penambatan diawali dengan penambatan KMP (redocking) dan diikuti penambatan meciadanol (cross docking). Evaluasi hasil penambatan didasarkan pada nilai afinitas ikatan (binding affinity), dimana kuat ikatan semakin baik dengan nilai yang semakin negatif (Salahudeen \& Nistala, 2017). Pose ikatan, nilai rootmean-square deviation (RMSD), dan interaksi juga diperoleh selama penambatan.

Validasi proses penambatan dilakukan melalui penambatan ulang KMP dengan cara mengambil KMP dari 5AUX atau 5AV3 dan memasukkannya kembali dalam situs ikatnya. Proses ini menghasilkan pose ikat dan konformasi KMP terbaik yang selanjutnya disejajarkan dengan KMP dalam kristal 5AUX atau 5AV3. Penyejajaran memberikan nilai RMSD masing-masing sebesar 1,750 ̊ dan 1,749 ̊ untuk 5AUX dan 5AV3 (Gambar 2). RMSD berhubungan dengan penyimpangan posisi ikat KMP hasil penambatan ulang terhadap posisi ikat KMP dalam kristal dan dapat diterima apabila bernilai kurang dari 2,0 (Allen \& Rizzo, 2014). Analisis interaksi menunjukkan KMP hasil penambatan ulang berinteraksi dengan 5AUX dan 5AV3 melalui ikatan hidrogen dengan residu Val96 dan Glu94, dan melalui ikatan polar dengan residu Leu95, Ala40, Ile160, Val27, Leu19, Gly20, Gly22, Ser21, Asp161, Lys42, dan Met146. KMP hasil penambatan ulang memiliki interaksi yang sama dengan KMP dalam kristal 5AUX dan 5AV3. Nilai RMSD $(<2,0 \AA)$ dan interaksi yang terjadi menginformasikan bahwa proses penambatan telah valid.

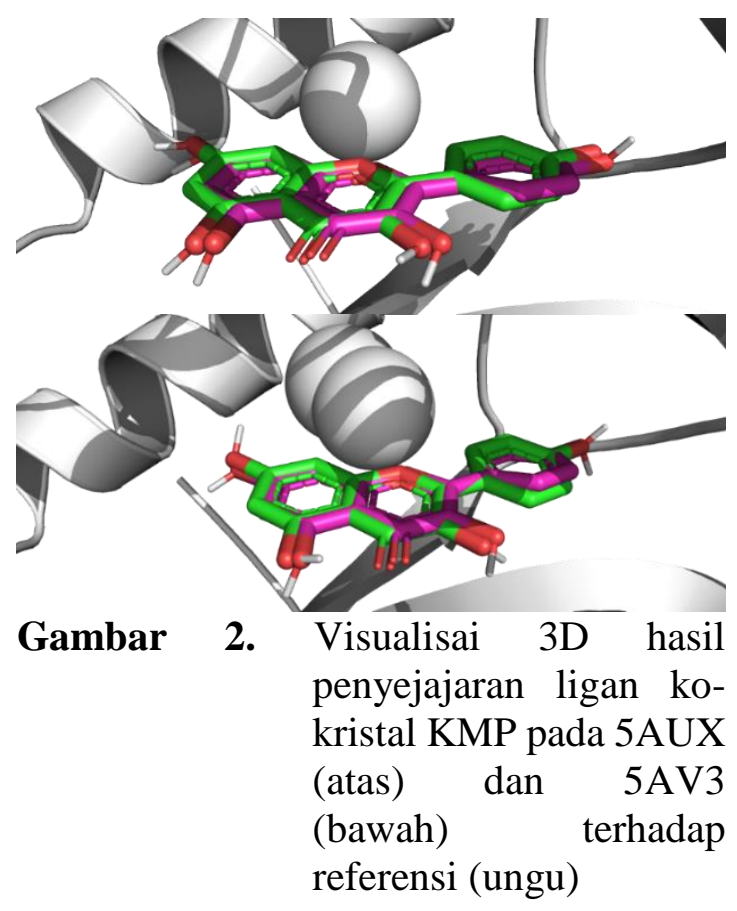

Selanjutnya, penambatan meciadanol dilakukan dengan prosedur dan koordinat gridbox yang sama sebagaimana penambatan ulang KMP. Penambatan meciadanol terhadap 5AUX memberikan 5 pose terbaik, sedangkan terhadap 5AV3 menghasilkan 6 pose terbaik. Afinitas ikatan terbaik pada hasil penambatan meciadanol terhadap 5AUX sebesar -7,4 $\mathrm{kkal} / \mathrm{mol}$ sedangkan terhadap 5AV3 sebesar $-7,0 \mathrm{kkal} / \mathrm{mol}$. Berdasarkan hasil ini, meciadanol cukup berpotensi sebagai agen antikanker yang ditandai dengan nilai afinitas ikatan yang negatif. Namun demikian, KMP menunjukkan aktivitas yang lebih baik dari meciadanol dengan afinitas ikatan yang lebih rendah yaitu sebesar -8,7 kkal/mol untuk 5AUX dan $8,9 \mathrm{kkal} / \mathrm{mol}$ untuk 5AV3. Hasil ini berkaitan dengan kerangka struktur 
meciadanol berupa flavanol yang berbeda dengan KMP yang berstruktur flavonol (Gambar 3). Gugus karbonil $(\mathrm{C}=\mathrm{O})$ dalam flavonol berperan penting, namun tidak demikian dengan gugus hidroksil pada posisi C3' meciadanol. Gugus metoksi $\left(\mathrm{OCH}_{3}\right)$ posisi $\mathrm{C} 3$ meciadanol diduga juga berperan dalam penurunan nilai afinitas ikatan. Hasil ini sesuai dengan laporan sebelumnya yang menyatakan kerangka flavonol lebih baik dari pada flavanol (Yokoyama et al., 2015).<smiles>OC1Cc2ccccc2OC1c1ccccc1</smiles>

flavanol<smiles>O=C1c2ccccc2OC(c2ccccc2)C1O</smiles>

flavonol

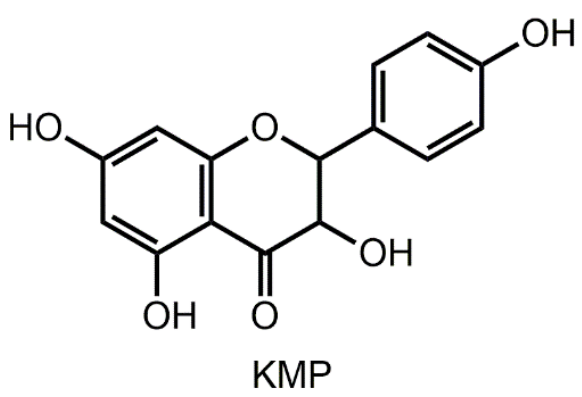

Gambar 3. Struktur flavanol, flavonol, dan KMP

Visualisasi interaksi (Gambar 4) menginformasikan bahwa meciadanol berinteraksi dengan 5AUX melalui ikatan hidrogen dengan residu Val96, Ala25, dan Lys42, sedangkan interaksi ikatan hidrogen meciadanol dengan 5AV3 terjadi melalui residu Val96, Ala25, Lys42, dan Gly22. Meciadanol juga berinteraksi dengan 5AUX dan 5AV3 melalui ikatan polar dengan residu Leu19, Met146,
Ala40, Ile160, Asp161, Ser21, Val27, Gly20, Glu100.
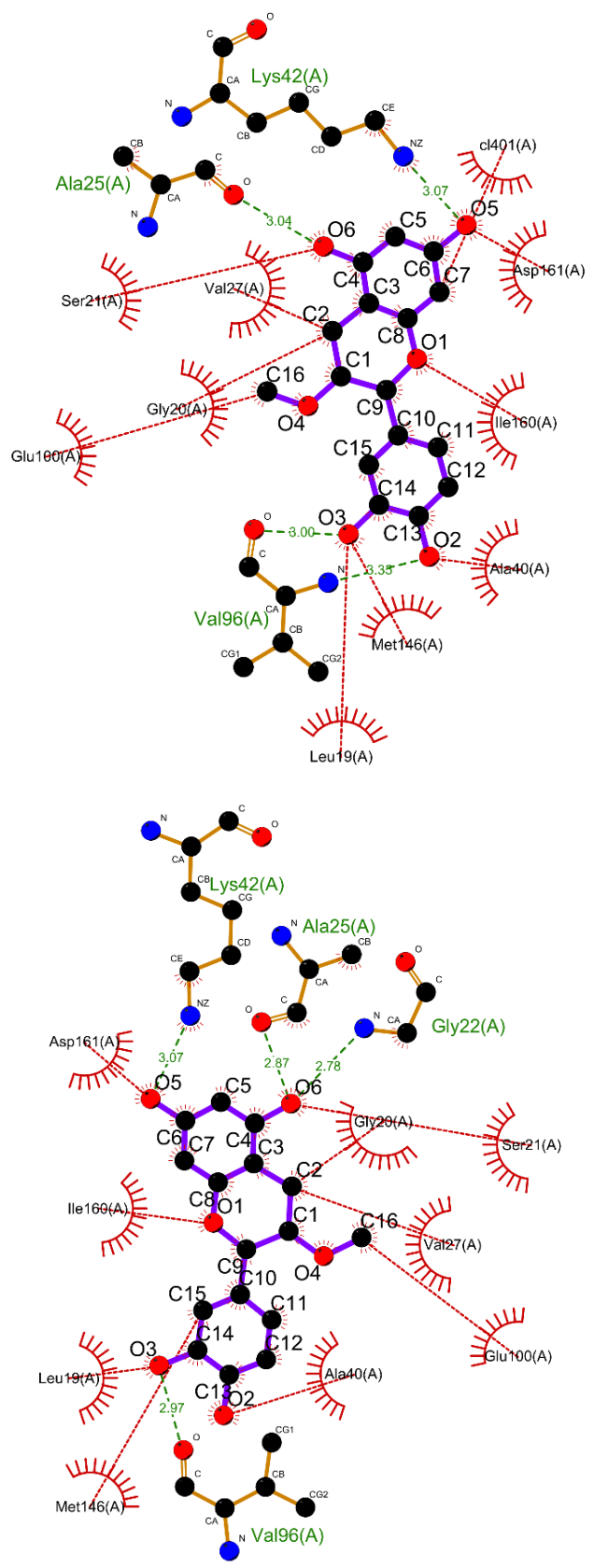

Gambar 4. Visualisasi Interaksi 2D Meciadanol dengan 5AUX (atas) dan 5AV3 (bawah) 
Sifat fisikokimia dan profil ADMET

Evaluasi drug-likeness dilakukan melalui sifat fisikokimia distribusi berat molekul, koefisien partisi oktanol air $(\operatorname{LogP})$, jumlah akseptor ikatan hidrogen (nHBA), dan jumlah donor ikatan hidrogen (nHBD) berdasarkan aturan Lipinski. Sifat fisikokimia meciadanol sebagaimana dapat dilihat pada Tabel 1 memperlihatkan bahwa meciadanol memiliki berat molekul 304,298, LogP sebesar 2,2002, dan nHBA dan nHBD masing-masing sebanyak 6 dan 4 . Meciadanol memenuhi kriteria aturan Lipinski untuk kandidat obat yaitu i) berat molekul $<500$ Dalton, ii) $\log \mathrm{P}<5$, iii) nHBD $<5$, iv) nHBA $<10$ (Lipinski, 2000). Nilai LogP diketahui berhubungan erat dengan hidrofilisitas, dimana semakin tinggi nilainya maka hidrofilisitas akan turun dan memperburuk penyerapan dan permeasi. Di sisi yang lain, laju penyerapan dapat ditingkatkan dengan berat molekul yang rendah. Berdasarkan hasil ini, meciadanol merupakan kandidat obat oral karena tidak melanggar aturan Lipinski. Pemenuhan seluruh kriteria dengan maksimal satu pelanggaran dalam aturan Lipinski mengindikasikan pencapaian penyerapan dan permeabilitas yang baik. Selanjutnya, TPSA meciadanol sebesar 126,346 $\AA^{2}$ yang termasuk dalam kategori moderat $\left(<140 \AA^{2}\right)$ mendukung permeabilitas meciadanol yang baik (Daina \& Zoete, 2016). Nilai TPSA juga mempengaruhi dalam penetrasi sistem saraf pusat (Blake, 2000; Chico et al., 2009).

Tabel 1. Sifat fisikokimia meciadanol berdasarkan aturan Lipinski

\begin{tabular}{lc}
\hline \multicolumn{1}{c}{ Parameter } & Nilai \\
\hline Berat molekul & 304,29 \\
$\begin{array}{l}\text { Koefisien partisi oktanol-air } \\
\text { (LogP) }\end{array}$ & 2,2002 \\
Jumlah akseptor ikatan hidrogen & 6 \\
Jumlah donor ikatan hidrogen & 4 \\
Topological surface area & 126,34 \\
\hline
\end{tabular}

Aturan Ghose, Veber, Egan, dan Muegge lebih lanjut dipelajari untuk meciadanol dengan parameter tambahan berupa jumlah atom, jumlah atom aromatis, Csp3, rotatable bonds, molar refractivity, koefisien partisi oktanol-air yang melibatkan faktor koreksi dan knowledge-based library (XLogP) dan koefisien partisi oktanol-air berdasar system fragmen Wildman dan Crippen (WLogP) (Cheng et al., 2007; Wildman \& Crippen, 1999). Tabel 2 menunjukkan bahwa meciadanol memenuhi aturan Ghose dengan kriteria jumlah atom 20-70, berat molekul 160-480, refraktivitas 40130, WLogP -0,4 hingga 5,6, aturan Veber dengan kriteria rotatable bonds kurang dari 10, nilai TPSA kurang dari 140, aturan Egan dengan kriteria WLogP kurang dari 5,88, nilai TPSA kurang dari 131,6, dan aturan Muegge dengan kriteria berat molekul 200-600, jumlah cincin aromatik kurang dari 7 , jumlah heteroatom kurang dari 1 , jumlah akseptor ikatan hidrogen kurang dari 10, jumlah donor ikatan hidrogen kurang dari 5; XLogP -2 hingga 5 , rotatable bonds kurang dari 15 , dan nilai TPSA kurang dari 150 (Veber et al., 2002; Egan et al., 2000; Ghose et al., 1999; Muegge et al., 2001).

Tabel 2. Sifat fisikokimia meciadanol berdasarkan aturan Veber dan Ghose

\begin{tabular}{lc}
\hline \multicolumn{1}{c}{ Parameter } & Nilai \\
\hline Jumlah atom & 22 \\
Jumlah atom aromatis & 12 \\
Csp3 & 0,25 \\
Jumlah rotatable bonds & 2 \\
Molar refractivity & 79,06 \\
XlogP & 0,90 \\
WLOgp & 1,88 \\
Ghose & Ya \\
Veber & Ya \\
Egan & Ya \\
Muegge & Ya \\
Skor bioavailabilitas & 0,55 \\
\hline
\end{tabular}


Prediksi ADMET dengan pkCSM, sebagaimana dapat dilihat pada Tabel 3, menunjukkan meciadanol dapat terserap dengan baik dalam intestinal manusia (79\%) dan melalui kulit $(\operatorname{logKp}-2,735)$ meskipun dengan kelarutan dalam air dan permeabilitas Caco2 yang cukup terbatas. Evaluasi penyerapan menginformasikan bahwa meciadanol bertindak sebagai substrat P-glikoprotein sehingga akan dikeluarkan dari sel. Meciadanol dapat terdistribusi secara merata dengan konsentrasi yang sama dalam plasma darah (volume distribusi $0,894>0,45$ ) dan mempunyai efikasi cukup bagus yang ditandai oleh fraksi tak terikat sebesar 0,234 . Namun, meciadanol memiliki permeabiltas BBB yang rendah ( $\log \mathrm{BB}<$ -1) dan tidak mampu menembus sistem saraf pusat $(\log$ PS $<-3)$.

Tabel 3. Hasil prediksi ADMET meciadanol

\begin{tabular}{ll}
\hline Parameter & Nilai \\
\hline Kelarutan dalam air & $-3,258$ \\
Permeabilitas Caco2 & $-0,224$ \\
Penyerapan intestinal manusia & 79,253 \\
Permeabilitas kulit & $-2,735$ \\
Substrat P-glikoprotein & Ya \\
Inhibitor P-glikoprotein I & Tidak \\
Inhibitor P-glikoprotein II & Tidak \\
VDss manusia & 0,894 \\
Fraksi tak terikat manusia & 0,234 \\
Permeabilitas BBB & $-1,099$ \\
Permeabilitas CNS & $-3,174$ \\
Substrat CYP3A4 & Tidak \\
Inhibitor CYP1A2 & Tidak \\
Inhibitor CYP2C19 & Tidak \\
Inhibitor CYP2C9 & Tidak \\
Inhibitor CYP2D6 & Tidak \\
Inhibitor CYP3A4 & Tidak \\
Total clearance & 0,252 \\
Substrat renal OCT2 & Tidak \\
Toksisitas AMES & Tidak \\
Dosis toleransi maksimum & 0,142 \\
\hline
\end{tabular}

$\begin{array}{ll}\text { Inhibitor hERG I } & \text { Tidak } \\ \text { Inhibitor hERG II } & \text { Tidak } \\ \text { Toksisitas akut tikus oral } & 2,359 \\ \text { Toksisitas kronis tikus oral } & 2,456 \\ \text { Hepatotoksisitas } & \text { Tidak } \\ \text { Sensitisasi kulit } & \text { Tidak } \\ \text { Toksisitas } T \text {. pyriformis } & 0,413 \\ \text { Toksisitas Minnow } & 3,269\end{array}$

Isoform sitokrom $\quad \mathrm{P} 450$
(CYP1A2/CYP2C19/CYP2C9/CYP2D6/ CYP3A4) merupakan sekelompok enzim yang penting dalam detoksifikasi melalui oksidasi xenobiotic. Meciadanol tidak bertindak sebagai substrat maupun inhibitor isoform CYP450 sehingga tidak mempengaruhi metabolisme dan tidak menimbulkan kontraindikasi. Hal ini didukung oleh informasi bahwa meciadanol tidak berfungsi sebagai substrat renal organic cation transporter 2 (OCT2) yang berperan penting dalam disposisi dan pembersihan obat dan senyawa endogen di renal. Ekskresi meciadanol yang cukup baik (log $\mathrm{ml} / \mathrm{min} / \mathrm{kg}=0,252$ ) juga diprediksi oleh deskriptor total clearance yang berhubungan dengan bioavailabilitas. Lebih lanjut, meciadanol tidak menunjukkan toksisitas AMES, tidak berfungsi sebagai inhibitor human ether-ago-go (hERG) yang berhubungan dengan channel kalium, tidak menunjukkan hepatotoksisitas, tidak menimbulkan sensitisasi pada kulit, mempunyai dosis toleransi maksimum yang rendah, dan tidak toksik terhadap Flathead Minnows. Meskipun demikian, meciadanol diketahui toksik terhadap tikus dan T. pyriformis.

\section{Kesimpulan}

Penyelidikan potensi antikanker meciadanol secara in silico telah dilakukan. Penambatan meciadanol terhadap protein DAPK1 (kode 5AUX dan 5AV3) dilakukan dengan Autodock Vina sedangkan sifat fisikokimia dan profil ADMET meciadanol dianalisis dengan 
SwissADME dan pkCSM. Penambatan meciadanol terhadap 5AUX dan 5AV3 memberikan afinitas ikatan masingmasing sebesar -7,4 kkal/mol dan -7,0 $\mathrm{kkal} / \mathrm{mol}$. Analisis sifat fisikokimia menyatakan bahwa meciadanol tidak melanggar aturan Lipinski, Ghose, Veber, Egan, dan Muegge. Meciadanol menunjukkan profil ADMET yang cukup baik berdasarkan parameter evaluasi masing-masing deskriptor.

\section{Saran}

Penelitian lanjutan berupa simulasi dinamika molekular dapat dilakukan untuk memperoleh data predicted binding energy.

\section{Daftar Pustaka}

Allen WJ, Rizzo RC., 2014, Implementation of The Hungarian Algorithm to Account for Ligand Symmetry and Similarity in Structurebased Design, J. Chem. Inf. Model., 54(2), 518-529.

Blake JF, 2000, Chemoinformaticspredicting the Physicochemical Properties of "drug-like" Molecules, Curr. Opin. Biotechnol., 11(1), 104 107.

Branco A, Yoshikawa, FSY, Pietrobon AJ, Sato, MN, 2018, Role of Histamine in Modulating the Immune Response and Inflammation, Mediat. Inflamm., 2018, 9524075.

Cheng T, Zhao Y, Li X, Lin F, Xu Y, Zhang X, Li Y, Wang R, Lai L., 2007, Computation of Octanol-Water Partition Coefficients by Guiding an Additive Model with Knowledge, J. Chem. Inf. Model., 47, 2140-2148.

Chico LK, Van Eldik LJ, Watterson DM, 2009, Targeting Protein Kinases in Central Nervous System Disorders, Nat. Rev. Drug Discov., 8(11), 892909.

Cole JC, Nissink JWM, Taylor R, 2005, Protein-ligand Docking and Virtual Screening with GOLD in Virtual
Screening in Drug Discovery, $1^{\text {st }} \mathrm{Ed}$. Taylor \& Francis CRC Press, 379-415 Daina A, Michielin O, Zoete V., 2017, SwissADME: A Free Web Tool to Evaluate Pharmacokinetics, Druglikeness and Medicinal Chemistry Friendliness of Small Molecules, Sci. Rep., 7, 1-13.

Daina A, Zoete V., 2016, A BOILED-Egg to Predict Gastrointestinal Absorption and Brain Penetration of Small Molecules, ChemMedChem, 11, 1117-1121.

Dallakyan S, Olson AJ., 2015, SmallMolecule Library Screening by Docking with PyRx, in Chemical Biology: Methods in Molecular Biology, vol. 1263, J. E. Hempel, C. H. Williams, and C. C. Hong, Eds. New York, NY: Springer New York, 243-250.

Drie JH, 2005, Pharmacophore-Based Virtual Screening: A Partical Prespective. in Virtual Screening in Drug Discovery, J. Alvarez \& B. Shoichet, Eds. $1^{\text {st }}$ Ed. Taylor \& Francis CRC Press.

Egan WJ, Merz KM, Baldwin JJ., 2000, Prediction of Drug Absorption Using Multivariate Statistics, J. Med. Chem., 43, 3867-3877.

Ghose AK, Viswanadhan VN, Wendoloski JJ., 1999, A Knowledge-Based Approach in Designing Combinatorial or Medicinal Chemistry Libraries for Drug Discovery. 1. A Qualitative and Quantitative Characterization of Known Drug Databases, J. Comb. Chem, 1, 55-68.

Jász Á, Rák Á, Ladjánszki I, Cserey G., 2019, Optimized GPU Implementation of Merck Molecular Force Field and Universal Force Field, J. Mol. Struct., 1188, 227-233.

Konturek SJ., Kitler, ME, Brzozowski T, Radecki T., 1986, Gastric Protection by Meciadanol A New Synthetic flavonoid-Inhibiting Histidine Decarboxylase, Dig. Dis. Sci., 31(8), 847-852. 
Lipinski CA, 2000, Drug-like Properties and the Causes of Poor Solubility and Poor Permeability, J. Pharmacol. Toxicol. Methods, 44(1), 235-249.

Mirzaei H, Zarbafian S, Villar E, Mottarella S, Beglov D, Vajda S, Paschalidis IC, Vakili P, Kozakov D., 2015, Energy Minimization on Manifolds for Docking Flexible Molecules, J. Chem. Theory Comput., 11(3), 1063-1076.

Moya-García AA, Pino-Ángeles A, Sánchez-Jiménez F, Urdiales JL, Medina MA, 2021, Histamine, Metabolic Remodelling and Angiogenesis: A Systems Level Approach, Biomolecules, 11, 415.

Muegge I, Heald SL, Brittelli D., 2001, Simple Selection Criteria for Druglike Chemical Matter," J. Med. Chem., 44, 1841-1846.

Nguyen PH, Cho, J., 2021, Pathophysiological Roles of Histamine Receptors in Cancer Progression: Implications and Perspectives as Potential Molecular Targets, Biomolecules, 11(1232), 126.

Nukata M, Hashimoto T, Yamamoto I, Iwasaki N, Tanaka M, Asakawa Y, 2002, Neogrifolin Derivatives Possessing Anti-Oxidative Activity from The Mushroom Albatrellus ovinus, Phytochemistry, 59, 731-737.

Park K., 2019, A Review of Computational Drug Repurposing, Transl. Clin. Pharmacol., 27(2); 59-63.

Pires DEV, Blundell TL, Ascher DB., 2015, pkCSM: Predicting SmallMolecule Pharmacokinetic and Toxicity Properties Using GraphBased Signatures, J. Med. Chem., 58, 4066-4072.

Salahudeen MS, Nishtala PS., 2017, An Overview of Pharmacodynamic Modelling, Ligand-binding Approach and Its Application in Clinical Practice, Saudi Pharm. J., 25(2), 165175.
Trott O, Olson AJ., 2009, AutoDock Vina: Improving the Speed and Accuracy of Docking with A New Scoring Function, Efficient Optimization, and Multithreading, J. Comp. Chem, 31(2), 455-461.

Veber DF, Johnson SR, Cheng HY, Smith BR, Ward, KW, Kopple KD., 2002, Molecular Properties That Influence the Oral Bioavailability of Drug Candidates, J. Med. Chem., 45, 26152623.

Wildman SA, Crippen GM., 1999, Prediction of Physicochemical Parameters by Atomic Contributions, J. Chem. Inf. Model. 39, 868-873.

Ye M, Luo X, Li L, Shi Y, Tan M, Weng X, Li W, Liu J, Cao Y, 2007, Grifolin, A Potential Antitumor Natural Product from The Mushroom Albatrellus confluens, Induces Cellcycle Arrest in G1 Phase via The ERK1/2 pathway, Cancer Lett., 258, 199-207.

Yokoyama T, Kosaka, Y, Mizuguchi, M, 2015, Structural Insight into the Interactions between DeathAssociated Protein Kinase 1 and Natural Flavonoids, J. Med. Chem., 58(18), 7400-7408.

Wu Z, Li, Y., 2017, Grifolin exhibits anticancer activity by inhibiting the development and invasion of gastric tumor cells, Oncotarget, 8, 2145421460. 